\title{
Enrichment of lecithin with n-3 fatty acids by acidolysis using immobilized phospholipase A1
}

\author{
By Hugo S. Garcia ${ }^{1,2}$, In-Hwan Kim³, Arnoldo Lopez-Hernandez ${ }^{1,2}$ and Charles G. Hill, Jr. *
}

${ }^{1}$ Department of Chemical and Biological Engineering, University of Wisconsin-Madison.

1415 Engineering Dr. Madison, WI 53706

${ }^{2}$ UNIDA, Instituto Tecnologico de Veracruz. M.A. de Quevedo \# 2779, Veracruz, Ver. 91897, México.

${ }^{3}$ Department of Food and Nutrition, College of Health Sciences, Korea University, Seoul 136-703, Korea

*Corresponding author: hill @ engr.wisc.edu

\section{RESUMEN}

Enriquecimiento de lecitina con ácidos grasos n-3 por acidolisis con fosfolipasa A1 inmovilizada.

Una preparación comercial de fosfolipasa A1 (Lecitase $^{\circledR}$ Ultra) fue inmovilizada por adsorción sobre Duolite ${ }^{\circledR}$ y empleada para catalizar la incorporación de ácidos grasos n-3 en lecitina. Las isotermas de adsorción mostraron que en 12 horas de contacto se depositó la mayor cantidad de enzima sobre el soporte. Las mejores condiciones para la adsorción se encontraron a un valor de $\mathrm{pH}$ de 7 y $50^{\circ} \mathrm{C}$. Las mezclas de reacción consistieron en lecitina y un saponificado de concentrado de aceite de pescado (78.4 mol \% EPA+DPA+DHA) a relaciones molares de 1:2 a 1:10. Una mezcla de reacción típica consistió de $2 \mathrm{~g}$ de sustratos y $200 \mathrm{mg}$ del preparado enzimático en un reactor en lotes. Las velocidades de reacción mas altas se encontraron cuando se empleó una relación molar de sustratos de 1:8 (lecitina:ácidos grasos totales). El preparado enzimático secado a $\mathrm{pH}$ de 8.0 a $50 \circ 60^{\circ} \mathrm{C}$ produjo las más altas incorporaciones de ácidos grasos n-3 en el fosfolípido después de $24 \mathrm{~h}$ de reacción.

PALABRAS CLAVE: Aceite de pescado - Fosfolípidos Interesterificación - Omega-3.

\section{SUMMARY}

Enrichment of lecithin with n-3 fatty acids by acidolysis using immobilized phospholipase A1.

A commercial phospholipase A1 (Lecitase ${ }^{\circledR}$ Ultra) was immobilized by physical adsorption on Duolite ${ }^{\circledR}$ and then used to mediate the incorporation of omega-3 fatty acids into lecithin. Adsorption isotherms showed that $12 \mathrm{~h}$ of contact were sufficient to deposit most of the enzyme onto the carrier. $\mathrm{A} \mathrm{pH}$ of 7 and $50^{\circ} \mathrm{C}$ were the best conditions for adsorption. Reaction mixtures consisting of lecithin and a saponified fish oil concentrate $(78.4 \mathrm{~mol} \%$ EPA+DPA+DHA) were prepared at molar ratios ranging from 1:2 to 1:10. Typically $2 \mathrm{~g}$ of total substrates and $200 \mathrm{mg}$ of enzyme preparation were employed in batch reactor trials. The fastest reaction rates were observed when a substrate mole ratio of 1:8 (lecithin:total fatty acids) was employed. Use of the enzyme preparation dried at $\mathrm{pH} 8$ and reaction temperatures of 50 and $60^{\circ} \mathrm{C}$ produced the greatest extent of incorporation of the indicated n-3 fatty acids into the phospholipid after $24 \mathrm{~h}$ of reaction.

KEY-WORDS: Fish oil - Interesterification - Omega-3 Phospholipids.

\section{INTRODUCTION}

Phospholipids (PL) constitute an important group of polar lipids that are present and abundant in all biological membranes. Phospholipids play a crucial role in the biochemistry and physiology of cells (Reddy et al., 2005). Moreover, PL and their partial hydrolysis products, lysophospholipids, have a wide variety of applications in the food, cosmetic, and pharmaceutical industries. The properties of PL depend to a great extent on the constituent fatty acid residues and the polar moiety bound to the glycerol backbone (Mustranta et al., 1995). Phospholipids containing specific fatty acid residues can be obtained by physical separation/fractionation of mixtures of naturally occurring phospholipids, followed by appropriate chemical modification of the resulting product. The technology currently employed for this purpose involves replacement of the native fatty acid residues in the parent phospholipids by desired acyl substituents using enzymes as biocatalysts (Mutua and Akoh, 1993).

Among the lipids commonly used in formulating nutraceuticals are n-3 fatty acids from fish oils, specifically eicosapentaenoic and docosahexaenoic acids (EPA and DHA, respectively). The health benefits of these lipids are attested to by a large body of scientific evidence concerning prevention of coronary heart disease and a variety of other ailments. Consequently, there is a growing demand from the manufacturers of pharmaceuticals and dietary supplements for these fatty acids in triacylglycerol and/or phospholipid form for a variety of medical and health-related applications (Haraldsson and Thorarensen, 1999). In addition, modified phospholipids containing saturated short and medium chain length fatty acids have promising food applications because of enhanced thermal stability, better emulsifying properties and improved resistance to oxidation Vikbjerg et al. (2005a).

Several studies and reviews have been published concerning the modification of phospholipids using physical, chemical and enzymatic methods (Adlercreutz et al., 2002; Van Nieuwenhuyzen, 1981; 
Joshi et al., 2006; Lilja-Hallberg and Härröd, 1995; Mutua and Akoh, 1993; Hossen and Hernandez, 2005; Vikbjerg et al., 2005b). Several review papers provide comprehensive compilations of reports on the enzymatic modification of PL and their industrial applications (D'Arrigo and Servi, 1997; De Maria et al., 2007; Guo et al., 2005; Servi, 1999, Van Nieuwenhuyzen, 1981). Specific reports concerning the incorporation of $\mathrm{n}-3$ fatty acids in PL have been published by Haraldsson and Thorarensen (1999), Hosokawa et al., (1998), Peng et al., (2002), Totani and Hara (1991) and Kim et al. (2007). In addition, several authors have reported the immobilization of phospholipases on different support materials for use in modification of different PL via a variety of chemical reactions including hydrolysis with phospholipase A2 (Madoery et al., 1995; Kim et al., 2001), transphosphatidylation (Dittrich and UlbrichHofman, 2001), phosphatidylglycerol synthesis (Wang et al., 1997) with phospholipase D, or acidolysis with phospholipase A1 (Vijeeta et al., 2004 or $A_{2}$ (Lilja-Hallberg and Härröd, 1995; Vikbjerg et al., 2007).

The purposes of the present work were to immobilize a commercial phospholipase A1 (Lecitase Ultra $^{\circledR}$ ) by adsorption on an ionic resin, and then to evaluate its ability to catalyze the exchange of the fatty acid residues naturally present in lecithin by acidolysis with n-3 fatty acids obtained from fish oil.

\section{MATERIALS AND METHODS}

\subsection{Materials and reagents}

Lecitase Ultra $^{\circledR}$ was a gift from NOVO (Salem, VA), while Duolite A568 was a gift from Rohm and Haas (Philadelphia, PA). Lecithin (95\% phosphatidylcholine, soy PC) was purchased from Avanti Polar Lipids (Alabaster, AL). Concentrated fish oil (03/55 TG fish oil) was a generous gift from Ocean Nutrition Canada (Dartmouth, NS). The Coomassie Blue reagent kit for protein analysis was obtained from Pierce (Rockford, IL). All other reagents and HPLC grade solvents were purchased from SIGMA (St. Louis, MO) and used without further purification.

\subsection{Immobilization of the phospholipase}

The undiluted enzyme concentrate containing ca. $1.5 \%$ protein was mixed with an equal volume of solutions of $0.1 \mathrm{~N}$ Tris- $\mathrm{HCl}$ buffer set at $\mathrm{pH}$ values from 4 to 9 to assess the effect of $\mathrm{pH}$ on the extent of immobilization; $\mathrm{pH}$ values of enzyme solutions before and after immobilization were checked and no measurable differences were observed. The effect of the immobilization temperature (20 to $70^{\circ} \mathrm{C}$ ) was tested at $\mathrm{pH} 7$. In a typical immobilization experiment, $10 \mathrm{~mL}$ of enzyme suspension was mixed with $1 \mathrm{~g}$ of support (Duolite A568) and placed in an orbital shaker operating at $300 \mathrm{rpm}$ and the desired temperature. Samples $(50 \mu \mathrm{L})$ of the supernatant were withdrawn and mixed with $450 \mu \mathrm{L}$ of buffer for the analysis of protein content. After 24 $h$, the suspension of the immobilized enzyme was filtered to recover the enzyme on a filter paper. The solids were rinsed with $50 \mathrm{~mL}$ of buffer at the $\mathrm{pH}$ used for the immobilization step and then dried overnight in a vacuum oven at $30^{\circ} \mathrm{C}$. The dried preparations were subsequently used to catalyze the reactions involved in modification of the phospholipids.

\subsection{Preparation of substrates}

Saponified fish oil concentrate was prepared by mixing $100 \mathrm{~g}$ of fish oil with $100 \mathrm{~mL}$ of $1 \mathrm{M} \mathrm{NaOH}$ in methanol and $300 \mathrm{~mL}$ of ethanol. The mixture was heated and refluxed for 30 minutes; after cooling, the mixture was transferred to a $2 \mathrm{~L}$ separatory funnel and $200 \mathrm{~mL}$ of water and $400 \mathrm{~mL}$ of hexane were added. The resulting mixture was then stirred and allowed to separate. The upper layer was discarded. The lower layer containing the soap was transferred to another funnel, and concentrated $\mathrm{HCl}$ (ca. $120 \mathrm{~mL}$ ) was added until the $\mathrm{pH}$ reached 1-2. The lower layer was discarded, and $400 \mathrm{~mL}$ of hexane and $200 \mathrm{~mL}$ of water were added. The mixture was shaken and the lower layer discarded. A second wash with water was carried out and the lower layer was again discarded. The remaining hexane layer containing the free fatty acids was filtered through a bed of $\mathrm{Na}_{2} \mathrm{SO}_{4}$ and cleaned by passing through a glass column packed with activated silica gel (230-400 mesh) using nitrogen pressure to facilitate the filtration. Finally, the hexane was evaporated using a rotary evaporator. The resulting mixture of fatty acids was stored in a frozen state under nitrogen until used for reaction. The average molecular weight of the fatty acid mixture was calculated on the basis of the GC analysis and used to determine the amount of this mixture that should be added to the lecithin to prepare substrate mixtures containing molar ratios of lecithin to free fatty acids equal to $1: 2,1: 4,1: 6$, $1: 8$ and $1: 10$.

\subsection{Acidolysis reactions}

For all of the acidolysis reaction trials, a ratio of total substrates to enzyme of $10: 1$ (w/w) was employed. Typically, $2 \mathrm{~g}$ of the mixture of substrates were combined with $200 \mathrm{mg}$ of immobilized phospholipase and allowed to react in an orbital shaker operating at $300 \mathrm{rpm}$ and the desired temperature for periods as long as $24 \mathrm{~h}$. Samples corresponding to all of the substrate ratios of interest were exposed to the immobilized phospholipase preparation that had been dried at $\mathrm{pH}$ 7. The mixture of substrates and enzyme was subjected to orbital shaking (300 rpm) at $50^{\circ} \mathrm{C}$ and left to react for periods as long as $24 \mathrm{~h}$. Samples were withdrawn periodically to monitor the extent of incorporation of the desired fatty acids into lecithin. 
To study the effect of the $\mathrm{pH}$ used to prepare the immobilized phospholipase on the ability of this biocatalyst to incorporate the desired $n-3$ fatty acid residues, we conducted trials at $50^{\circ} \mathrm{C}$ involving an $1: 8$ mole ratio of lecithin to fatty acids and enzyme preparations dried at $\mathrm{pH}$ values ranging from 4 to 9 . The effect of adding water to the reaction mixture was also investigated in a series of trials involving the addition of $2,5,10,20$ or $50 \mathrm{mg}$ of water/g of total substrates (1:8 ratio of lecithin to fatty acids) followed by the use of a sonicating bath for 30 minutes prior to carrying out the reactions at $50^{\circ} \mathrm{C}$ for $24 \mathrm{~h}$. Finally, the combined effects of temperature and the addition of water were studied using a substrate ratio of 1:8 (lecithin/fatty acids) and enzyme preparations dried at $\mathrm{pH} 7$. Water was added at levels of $0,2,5,10,20$ or $50 \mathrm{mg} \mathrm{H}_{2} \mathrm{O} / \mathrm{g}$ of total substrates. The shaker was operated at $300 \mathrm{rpm}$ and temperatures of $20,30,40,50,60$ or $70^{\circ} \mathrm{C}$. Samples were withdrawn periodically during the $24 \mathrm{~h}$ of reaction.

\subsection{Analyses}

Soluble protein was determined via the method of Bradford (1976) using a Beckman DU-520 spectrophotometer to measure the absorbance at $595 \mathrm{~nm}$. BSA was employed as a standard, according to the assay method suggested by the supplier (Pierce). Total fatty acids in the fish oil concentrate and in lecithin were determined by direct methylation with $1 \mathrm{~N} \mathrm{HCl}$-methanol at $60^{\circ} \mathrm{C}$ for 30 minutes. Esterified fatty acids in the phospholipids and the reaction mixture were determined by alkali-based methylation. Typically, $100 \mu \mathrm{L}$ of reaction mixture was mixed with $1 \mathrm{~mL}$ of $0.5 \mathrm{~N}$ sodium methoxide in methanol; 5 minutes later, $100 \mu \mathrm{L}$ of water were added and the methyl esters were extracted with $2 \mathrm{~mL}$ of hexane. An

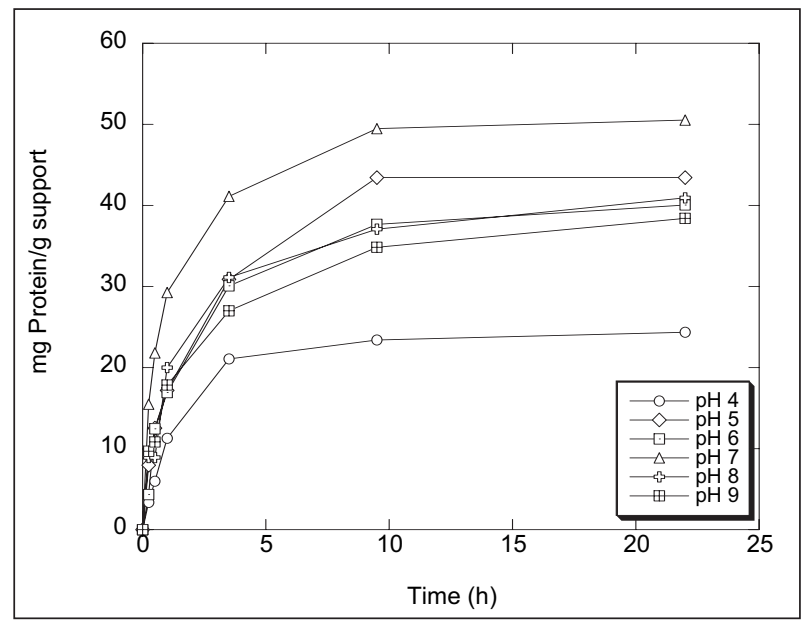

Figure 1

Effects of the $\mathrm{pH}$ of the soluble phospholipase preparation on the absorption isotherm of phospholipase A1. Immobilization involved mixing $5 \mathrm{~g}$ of liquid Lecitase ${ }^{\circledast}$ with $5 \mathrm{~mL}$ of Tris buffer, adjusted to the proper $\mathrm{pH}$. Then $1 \mathrm{~g}$ of Duolite ${ }^{\circledR}$ support was added, and the suspension was subjected to orbital shaking (300 rpm) at $50^{\circ} \mathrm{C}$. aliquot of the extract $(1 \mu \mathrm{L})$ was injected into an HP Model 5890 gas chromatograph fitted with a Supelcowax-10 fused silica capillary column (30 m $\times 0.25 \mathrm{~mm} \times 0.25 \mathrm{~mm}$ film thickness). Injector and FID temperatures were set at 240 and $250^{\circ} \mathrm{C}$, respectively. The temperature program involved heating from 180 to $230^{\circ} \mathrm{C}$ at $2^{\circ} \mathrm{C} / \mathrm{min}$ and then maintaining this temperature for additional 19 minutes.

Data analysis. Data from the various trials were analyzed by ANOVA and means were compared by the LSD test $(\alpha=0.05)$, using the statistical software package SPSS v. 11.

\section{RESULTS AND DISCUSSION}

Protein (phospholipase A1) adsorption isotherms for solution $\mathrm{pH}$ values ranging from 4 to 9 are shown in Figure 1. Although no bars for standard errors are indicated on the plot, the replicate trials revealed very little dispersion $(\approx 1.5 \%)$. Visual inspection of the data indicates that only $12 \mathrm{~h}$ of contact at $50^{\circ} \mathrm{C}$ are sufficient to approach maximum adsorption of the protein on the support. For the $\mathrm{pH}$ values of interest, maximum adsorption of the enzyme on the support (ca. $52 \mathrm{mg}$ protein/g support) was achieved under neutral conditions $(\mathrm{pH} 7)$. On the basis of this result and our desire to avoid potential denaturation of the enzyme with the concomitant loss of enzyme activity, we used $12 \mathrm{~h}$ of immobilization at $50^{\circ} \mathrm{C}$ to prepare the phospholipase used in subsequent experiments.

To assess the effect of temperature on the amount of protein adsorbed on the Duolite A568 support, we conducted a series of trials at $\mathrm{pH} 7$. The results corresponding to temperatures between 20 and $50^{\circ} \mathrm{C}$ are shown in Figure 2. Examination of this figure indicates that for times of adsorption greater

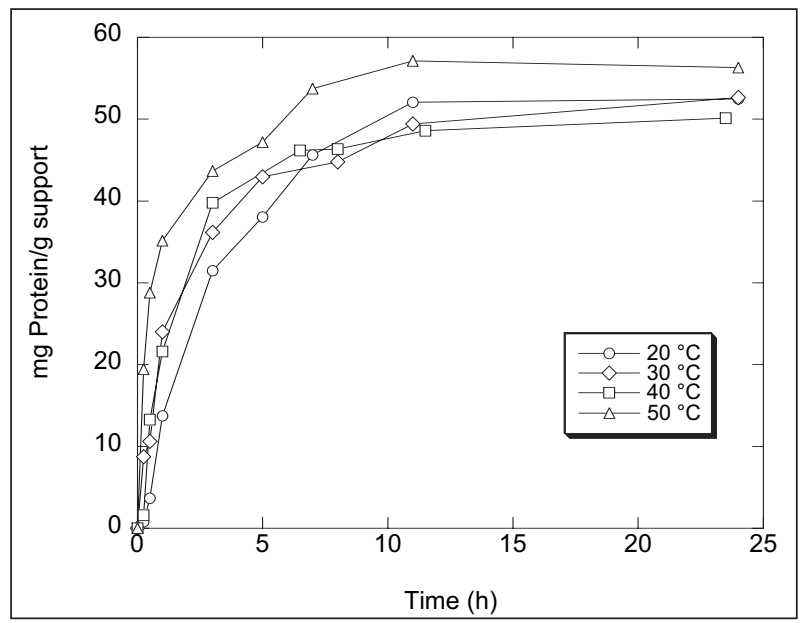

Figure 2

Effect of the immobilization temperature on the amount of protein absorbed into the Duolite ${ }^{\circledast}$ support.

Phospholipase solution $(10 \mathrm{~g})$ at $\mathrm{pH} 7$ was mixed with $1 \mathrm{~g}$ of support and placed in an orbital shaker operating at $300 \mathrm{rpm}$. The uncertainties in the data points are $\sim 1.5 \%$. 
than $8 \mathrm{~h}$ the effects of differences in temperature on protein adsorption were much less significant than the effects of differences in $\mathrm{pH}$ (cf. Figure 1). The highest temperature investigated $\left(50^{\circ} \mathrm{C}\right)$ was that at which maximum adsorption was observed. This value is close to that indicated by the manufacturer as the optimum reaction temperature for the enzyme $\left(55^{\circ} \mathrm{C}\right)$. Many investigators neglect the effect of temperature on immobilization and usually perform their immobilization procedure at room temperature. Our results suggest that this variable can be responsible for significant differences in the amount of protein adsorbed on the support. Using our procedure, we were able to immobilize ca. 52 $\mathrm{mg}$ of protein/g support from a suspension initially containing $75 \mathrm{mg}$ protein $/ \mathrm{g}$ support. Hence nearly $70 \%$ of the soluble enzyme was recovered in its immobilized form. These values are consistent with and are of the same order of magnitude as corresponding data obtained by Vikbjerg and coworkers (2007), who immobilized phospholipase A2 from suspensions of Amberlite XAD7 resin initially containing enzyme concentrations of $100 \mathrm{mg} / \mathrm{g}$ carrier. The immobilized enzyme product contained $72 \mathrm{mg} / \mathrm{g}$ carrier.

Gas chromatographic analysis of the saponified fish oil concentrate indicated that this substrate contained a total of $78.4 \mathrm{~mol} \%$ of the n-3 fatty acids EPA, DPA and DHA (12.7, 7.9 and $57.8 \mathrm{~mol} \%$, respectively). The only other fatty acid present in appreciable proportions was a C22:1 species (ca. $12 \%)$. To simplify the discussion, we have chosen to group the n-3 fatty acid residues and will subsequently refer to these species as total esterified n-3 fatty acids. For lecithin, on the other hand, the major fatty acid residues were palmitic $(14 \%)$, stearic $(4 \%)$, oleic $(11 \%)$, linoleic $(63 \%)$ and linolenic acids (6\%).

The effects of the different variables studied in this research on the extent to which acidolysis is able to incorporate n-3 residues into phospholipids are summarized in Figure 3. Panel A depicts the effect of the mole ratio of substrates (lecithin to fatty acids). Analysis of the data indicates that for our immobilized phospholipase A1, the greatest extent of incorporation of n-3 fatty acid residues was obtained at a substrate mole ratio of $1: 8$. By contrast, we reported earlier (Kim et al., 2007) that for the free (soluble) form of Lecitase Ultra the corresponding optimum substrate ratio was 1:10. Our results are very consistent with those reported by Haraldsson and Thorarensen (1999) for the preparation of a phosphatidylcholine (PC) rich in $\mathrm{n}-3$ residues using the immobilized lipase RM-IM. By contrast, Peng et al. (2002) reported that for the same RM-IM lipase, the best ratio was $1: 5$ to $1: 6$, while Mutua and Akoh (1993) found an optimum ratio of 1:2. An optimum ratio of 1:4.3 was reported by Hosokawa et al. (1998) for transesterification of PC with EPA when mediated by phospholipase A2. Moreover, for the incorporation of caprylic acid residues into PC in a continuous flow packed bed reactor containing lipase TL-IM, Vikbjerg et al. (2005ab) observed increased incorporation at mole ratios of $1: 3$ to $1: 15$ and $1: 3$ to $1: 35$. In light of the wide variations in the values of the "optimum» ratio of substrates (albeit for somewhat different chemical systems and enzymes) reported in the literature, it is impossible to arrive at a general conclusion as to what ratio of substrates is truly optimum if one desires to incorporate new fatty acid residues in a naturally occurring lecithin. Experimental verification of the optimum ratio will be necessary for proposed combinations of enzymes, fatty acids and lecithins.

The effect of adding water to the reaction medium is depicted in panel B of Figure 3. Inspection of these results indicates that the

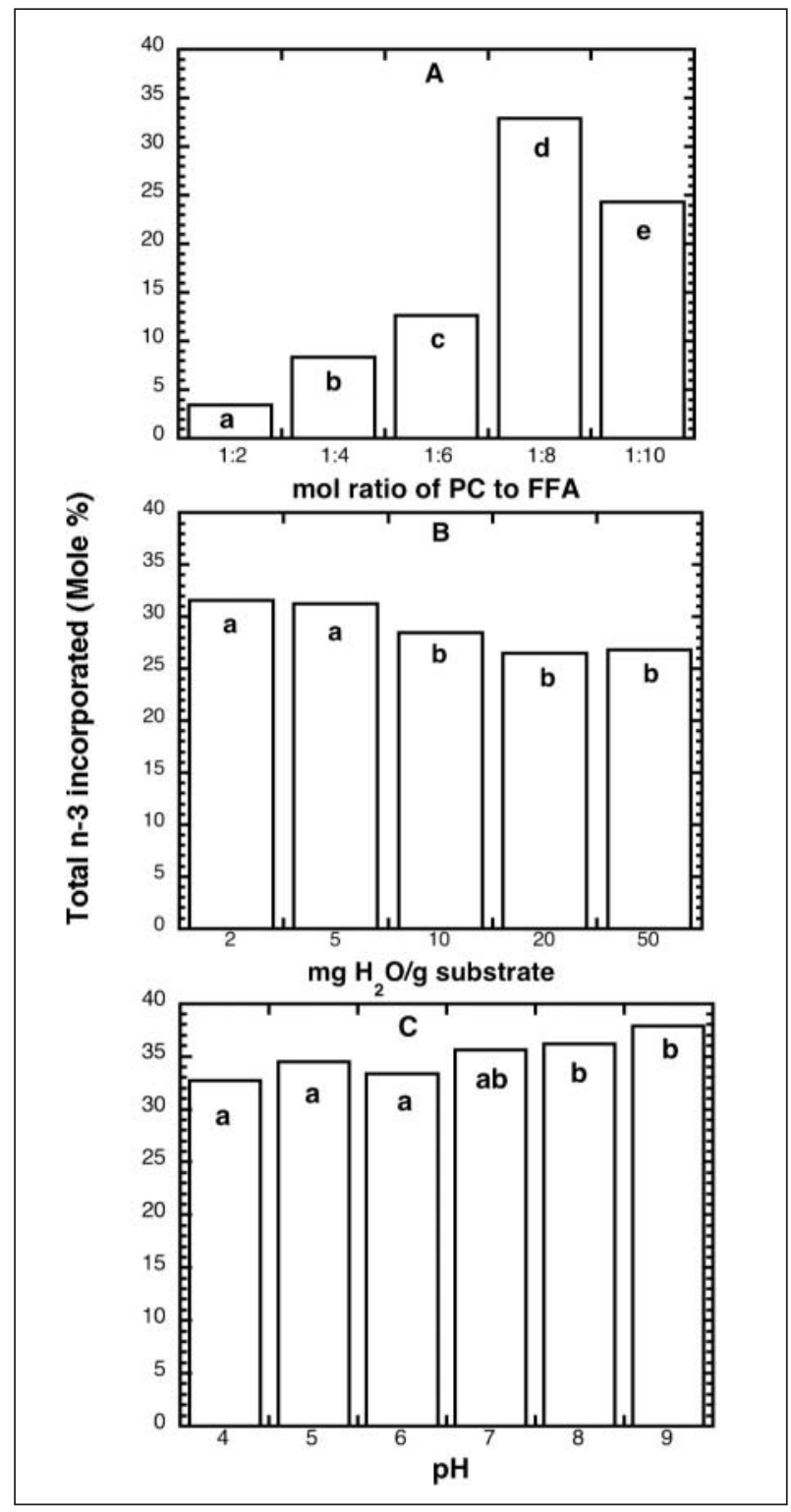

Figure 3

Effects of the molar ratio of substrates (phosphatidylcholine: fish oil free fatty acids, PC:FFA), (panel A); effects of added water (panel B); and effects of the $\mathrm{pH}$ used in enzyme preparation (panel C) on the extent of the incorporation of n-3 fatty acids into lecithin, expressed as mole per cent Different letters at the top of the bars indicate the statistical significance $(p<0.05)$ of the various treatments. 
greatest incorporation of $n-3$ fatty acids is achieved at the lowest levels of added water. Consequently in subsequent trials, we did not add any water to the reaction medium or the immobilized enzyme. The effects of adding water to the reaction mixture have been evaluated previously by different authors. (Haraldsson and Thorarensen 1999) reported that the addition of $5 \%(\mathrm{w} / \mathrm{w})$ water produced the greatest extent of incorporation of EPA in PC, but unfortunately their reaction conditions led to extensive hydrolysis as a side reaction; Vikbjerg et al. (2007) reported greater extents of acidolysis of PC by caprylic acid at water contents of $2-4 \%$. In an earlier study, Totani and Hara (1991) employed ca. $56 \%(\mathrm{w} / \mathrm{w})$ water (based on total substrates plus the enzyme) in a system comprised of sardine oil, phospholipids, hexane, and a lipase from $C$. cylindracea. They incorporated up to $18.4 \%$ PUFA after $48 \mathrm{~h}$ of reaction at $37^{\circ} \mathrm{C}$ in the presence of hexane. While they achieved slightly more incorporation than that obtained in the present work, the time their system needed to reach equilibrium was twice as long as that required in our work. Water content is a very important variable that affects both the rate and the selectivity of reactions catalyzed by lipases and phospholipases. The precise role that water plays in these reactions remains to be elucidated and has been the subject of extensive speculation. Nonetheless, it is clear that the water content of the reaction medium influences both the activity of the biocatalyst and the product distribution. Yields of the desired product are adversely affected by undesired hydrolysis reactions leading to formation of lysophosphatidylcholine (LPC). In trials in which no added water was present we were able to incorporate in our phospholipid products approximately $33 \%$ of the $n-3$ fatty acids from fish oil that were initially present as free fatty acids. This result was obtained using a 1:8 mole ratio of substrates (lecithin to fatty acids). Of the

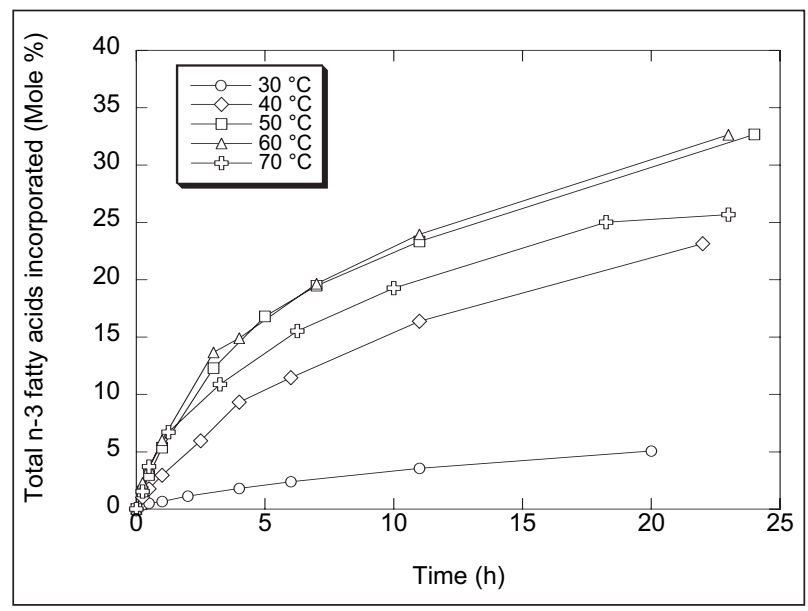

Figure 4

Effect of reaction temperature on the time course of the incorporation of $n-3$ fatty acids into lecithin.

The enzyme was immobilized at $\mathrm{pH}$ 8. The ratio of substrates was 1:8 (PC:FFA). The orbital shaker was operated at $300 \mathrm{rpm}$. The uncertainties in the data points are $\sim 1.5 \%$. products $34 \%$ was PC and $13.7 \%$ was LPC. Further studies of the effects of water on both reaction rates and the yields of PC and LPC are warranted.

Panel $C$ of Figure 3 depicts the extent of the incorporation of the $n-3$ fatty acids from fish oil in residue form as a function of the $\mathrm{pH}$ at which the enzyme was immobilized and dried. Although information provided by the manufacturer implied that the use of $\mathrm{pH}$ values of 6 and 7 was typical for this enzyme, we found that when the immobilized enzyme was dried and conditioned under slightly alkaline conditions $(\mathrm{pH}$ values 8 and 9) these biocatalysts produced slightly better incorporation of $\mathrm{n}-3$ fatty acids than were obtained when $\mathrm{pH}$ values below 7 were employed. These results are consistent with those of Wang and co-workers (1997) who reported that the highest activity of phospholipase D for the production of phosphatidylglycerol was obtained when the $\mathrm{pH}$ of the reaction medium was adjusted to values between 7 and 9. Moreover, Madoery and co-workers (1995) also reported an optimum pH near 8-8.5 for the activity of both the free or immobilized forms of phospholipase A2. Inspection of Panel $\mathrm{C}$ in Figure 3 indicates that even though $\mathrm{pH}$ is a variable that is commonly neglected in studies of enzyme immobilization, $\mathrm{pH}$ can have a very significant effect on the product yield obtained using these biocatalysts for a fixed period of time. In our case an increase of ca. $5 \%$ in the yield of the desired product can be obtained by employing a more appropriate $\mathrm{pH}$.

The effects of temperature on the rate and extent of the incorporation of the n-3 fatty acid residues of interest (the sum of EPA, DPA and DHA) are depicted in Figure 4. In a previous report by Kim et al. (2007), we indicated that for free (soluble) phospholipase A1 good conversions can be achieved at temperatures between 25 and $65^{\circ} \mathrm{C}$. By contrast, for the immobilized phospholipase A1 used in this work, the highest conversions were obtained at 50 and $60^{\circ} \mathrm{C}$. At $70^{\circ} \mathrm{C}$ the catalytic effect of the enzyme is diminished, presumably a consequence of temperature-induced denaturation of the phospholipase. Other investigators have reported optimal temperatures in a similar range; for example: (Lilja-Hallberg and Härröd 1995) suggested that for an immobilized phospholipase $\mathrm{A} 2$ a range of $45-60^{\circ} \mathrm{C}$ is optimum for the incorporation of n-3 PUFA into PC. For the free form of the same enzyme Vikbjerg (2007) and Egger (1997) observed distinct optima at $45^{\circ} \mathrm{C}$ and $40^{\circ} \mathrm{C}$, respectively. The conversions of free $n-3$ fatty acids to esterified residue form (up to $35 \%$ of the total esterified FA) achieved in the present work were higher than those obtained by other researchers employing phospholipases or lipases in similar synthesis schemes (Kim et al., 2007; Hara and Nakashima, 1996).

Reports from other groups and our own unpublished results suggest that a continuous flow reactor packed with phospholipase A1 immobilized on Duolite A568 would be able to achieve higher conversions more efficiently (at space times less 
than the corresponding batch reactor times) while simultaneously minimizing the migration of acyl groups (Vikbjerg et al., 2006). In a continuous flow packed bed reactor, the water activity and the operating conditions could be manipulated to obtain high yields and control the extent of undesirable hydrolysis reactions.

\section{CONCLUSIONS}

For immobilization of Lecitase ${ }^{\circledR}$ Ultra on Duolite A568 resin, maximum adsorption of the enzyme was achieved after $12 \mathrm{~h}$ at $50^{\circ} \mathrm{C}$ and $\mathrm{pH} 7$. For the immobilized enzyme catalyzed reaction of lecithin with free n-3 fatty acids from fish oil in a batch reactor, quasi-equilibrium conditions were reached in ca. $24 \mathrm{~h}$. When a substrate mole ratio of $1: 8$ (lecithin to FFA) was employed, no added water was present, and the time was sufficient to reach quasi equilibrium conditions at $50^{\circ} \mathrm{C}$, nearly $35 \%$ of the total esterified fatty acid residues were $n-3$ species (EPA, DPA or DHA). Further studies of the effect of water activity are needed to facilitate design and operation of a packed bed reactor for continuous interesterification of lecithin with free n3 fatty acids from fish oil.

\section{ACKNOWLEDGMENTS}

This work was supported by the University of Wisconsin Sea Grant Institute under grants from the National Sea Grant College Program, National Oceanic and Atmospheric Administration, US Department of Commerce, from the State of Wisconsin (Federal grant number NA 46 RG 0481, project number R/AQ-34). Additional support was provided by National Science Foundation Grant BES-0077524, and a U.S. Department of Agriculture Competitive Research Grant (Award Number 200135503-09912).

\section{REFERENCES}

Adlercreutz D, Budde, H, Wehtje E. 2002. Synthesis of phosphatidylcholine with defined fatty acid in the sn-1 position by lipase-catalyzed esterification and transesterification reaction. Biotechnol. Bioeng. 78, 403-411.

Bradford M. 1976. A Rapid and Sensitive Method for the Quantitation of Microgram Quantities of Protein Utilizing the Principle of Protein-Dye Binding. Anal. Biochem. 72, 248-254.

D’Arrigo P, Servi S. 1997. Using phospholipases for phospholipid modification. TIBTECH 15, 90-96.

De Maria L, Vind J, Oxenbøl KM, Svendsen A, Patkar S. 2007. Phospholipases and their industrial applications. Appl. Microbiol. Biotechnol. 74, 290-300.

Dittrich N, Ulbrich-Hofman R. 2001. Transphosphatidylation by immobilized phospholipase $\mathrm{D}$ in aqueous media. Biotechnol. Appl. Biochem. 34, 189-194.

Egger D, Wehtje E, Adlercreutz P. 1997. Characterization and optimization of phospholipase A2 catalyzed synthesis of phosphatidylcholine. Biochim. Biophys. Acta 1343, 76-84.

Guo Z, Vikbjerg AF, Xu X. 2005. Enzymatic modification of phospholipids for functional applications and human nutrition. Biotechnol. Adv. 23, 203-259.

Hara F, Nakashima T. 1996. Transesterification of phospholipids by acetone-dried cells of Rhizopus species immobilized on biomass support particles. $J$. Am. Oil Chem. Soc. 73, 657-659.

Haraldsson GG, Thorarensen A. 1999. Preparation of phospholipids highly enriched with n-3 polyunsaturated fatty acids by lipase. J. Am. Oil Chem. Soc. 76, 11431149.

Hosokawa M, Ito M, Takahashi K. 1998. Preparation of highly unsaturated fatty acid-containing phosphatidylcholine by transesterification with phospholipase A2. Biotechnol. Tech. 12, 585-586.

Hossen M, Hernandez E. 2005. Enzyme catalyzed synthesis of structured phospholipids with conjugated linoleic acid. Eur. J. Lipid Sci. Technol. 107, 730-736.

Joshi A, Paratkar SG, Thorat BN. 2006. Modification of lecithin by physical, chemical and enzymatic methods. Eur. J. Lipid Sci. Technol. 108, 363-373.

Kim IH, Garcia HS, Hill Jr. CG. 2007. Phospholipase A1catalyzed synthesis of phospholipids enriched in n-3 polyunsaturated fatty acid residues. Enz. Microb. Technol. 40, 1130-1135.

Kim J, Lee CS, Oh J, Kim BG. 2001. Production of egg yolk lysolecithin with immobilized phospholipase A2. Enz. Microb. Technol. 29, 587-592.

Lilja-Hallberg M, Härröd M. 1995. Enzymatic and nonenzymatic esterification of long polyunsaturated fatty acids and lysophosphatidylcholine in isooctane. Biocatal. Biotransfor. 12, 55-66.

Madoery R, Gattone CG, Fidelio G. 1995. Bioconversion of phospholipids by immobilized phospholipase A2. J. Biotechnol. 40, 145-153.

Mustranta A, Forssell P, Poutanen K. 1995. Comparison of lipases and phospholipases in the hydrolysis of phospholipids. Proc. Biochem. 30, 393-401.

Mutua LN, Akoh CC. 1993. Lipase-catalyzed modification of phospholipids: incorporation of n-3 fatty acids into biosurfactants. J. Am. Oil Chem. Soc. 70, 125-128.

Peng L, Xu X, Mu H, Høy CE, Adler-Nissen J. 2002. Production of phospholipids by lipase-catalyzed acidolysis: optimization using response surface methodology. Enz. Microb. Technol. 31, 523-532.

Reddy JRC, Vijeeta T, Karuna MSL, Rao BVSK, Prasad RBN. 2005. Lipase-catalyzed preparation of palmitic and stearic acid-rich phosphatidylcholine. J. Am. Oil Chem. Soc. 82, 727-730.

Servi S. 1999. Phospholipases as synthetic catalysts. In: WD Fessner (Ed.) Biocatalysis - From Discovery to Application (Topics in Current Chemistry). pp 127158. Springer Verlag, Berlin.

Totani Y, Hara S. 1991. Preparation of polyunsaturated phospholipids by lipase-catalyzed transesterification. J. Am. Oil Chem. Soc. 68, 848-851.

Van Nieuwenhuyzen W. 1981. The industrial uses of special lecithins: a review. J. Am. Oil Chem. Soc. 58, 886-888.

Vijeeta T, Reddy JRC, Rao BVSK, Karuna MSL, Prasad RBN. 2004. Phospholipase-mediated preparation of 1-ricinoleoyl-2-acyl-sn-glycero-3-phosphocholine from soya and egg phosphatidylcholine. Biotechnol. Lett. 26, 1077-1080.

Vikbjerg AF, Mu H, Xu X. 2005a. Lipase-catalyzed acyl exchange of soybean phosphatidylcholine in n-hexane: a critical evaluation of both acyl 
incorporation and product recovery. Biotechnol. Prog. 21, 397-404.

Vikbjerg AF, Mu H, Xu X. 2006. Elucidation of acyl migration during lipase-catalyzed production of structured phospholipids. J. Am. Oil Chem. Soc. 83, 607-614.

Vikbjerg AF, Mu H, Xu X. 2007. Synthesis of structured phospholipids by immobilized phospholipase A2 catalyzed acidolysis. J. Biotechnol. 128, 545-554.

Vikbjerg AF, Peng L, Mu H, Xu X. 2005b. Continuous production of structured phospholipids in a packed bed reactor with lipase from Thermomyces lanuginosa. J. Am. Oil Chem. Soc. 82, 237-242.

Wang XG, Qiu AY, Tao WY, Shen PY. 1997. Synthesis of phosphatidylglycerol from soybean lecithin with immobilized Phospholipase D. J. Am. Oil Chem. Soc. 74, 87-91. 